\title{
Erratum to: Camel milk peptide improves wound healing in diabetic rats by orchestrating the redox status and immune response
}

Hossam Ebaid ${ }^{1,2 *}$, Bahaa Abdel-salam²,3, Iftekhar Hassan ${ }^{1}$, Jameel Al-Tamimi ${ }^{1}$, Ali Metwalli, ${ }^{4,5}$ and Ibrahim Alhazza ${ }^{1}$

\section{Erratum}

After publication of the original article [1], it came to the authors' attention that an institution had been inadvertently omitted from the Acknowledgements section. The results of the paper are part of a funded project from the National Plan for Sciences, Technology and Innovation (MAARIFAH), King Abdualaziz City for Science and Technology, which should have been acknowledged in the original article.

\section{Author details}

'Department of Zoology, College of Science, King Saud University, P.O. Box 2455, Riyadh 11451, Saudi Arabia. ${ }^{2}$ Department of Zoology, Faculty of Science, El-Minia University, El-Minia, Egypt. ${ }^{3}$ Department of Biology, College of Science and Humanities in Quwiaya, Riyadh 11961, Saudi Arabia.

${ }^{4}$ Department of Food Science, College of Agriculture and Food Science, King

Saud University, Riyadh, Saudi Arabia. ${ }^{5}$ Department of Dairy, Faculty of

Agriculture, El-Minia University, El-Minia, Egypt.

Published online: 20 February 2017

\section{Reference}

1. Ebaid H, Abdel-Salam B, Hassan I, Al-Tamimi J, Metwalli A, Alhazza I. Camel milk peptide improves wound healing in diabetic rats by orchestrating the redox status and immune response. Lipids Health Dis. 2015;14:132. doi:10. 1186/s12944-015-0136-9.

\footnotetext{
* Correspondence: hossamebaid@yahoo.com

'Department of Zoology, College of Science, King Saud University, P.O. Box 2455, Riyadh 11451, Saudi Arabia

${ }^{2}$ Department of Zoology, Faculty of Science, El-Minia University, El-Minia,

Egypt
} 